Meta

Journal des traducteurs

Translators' Journal

\title{
Cultural Assertion in the African Autobiography
}

\section{Tony E. Afejuku}

Volume 35, numéro 4, décembre 1990

URI : https://id.erudit.org/iderudit/001857ar

DOI : https://doi.org/10.7202/001857ar

Aller au sommaire du numéro

Éditeur(s)

Les Presses de l'Université de Montréal

ISSN

0026-0452 (imprimé)

1492-1421 (numérique)

Découvrir la revue

Citer cet article

Afejuku, T. E. (1990). Cultural Assertion in the African Autobiography. Meta, 35(4), 389-700. https://doi.org/10.7202/001857ar d'utilisation que vous pouvez consulter en ligne.

https://apropos.erudit.org/fr/usagers/politique-dutilisation/ 


\section{CULTURAL ASSERTION IN THE AFRICAN AUTOBIOGRAPHY}

TONY E. AFEJUKU

University of Benin, Benin City, Nigeria

This essay affirms that cultural assertion is one of the dominant themes of the African autobiography. Among the autobiographies that eloquently illustrate this theme are The African Child by Guinean author Camara Laye, Child of Two Worlds and Facing Mount Kenya by Kenyan authors Mugo Gatheru and Jomo Kenyatta, respectively. Others are The Autobiography of An Unknown South African, by Naboth Mokgatle of South Africa, Kossoh Town Boy by Robert Wellsley Cole of Sierra Leone, and Years of Childhood by Wole Sokinka of Nigeria ${ }^{1}$.

Although different from one another in structural or narrative design, these works are important as cultural or communal autobiographies. This is not only because they demonstrate that there is unity in traditional African life, but also because they reveal that the urge to preserve the charms and specific qualities of the times that are no more, of the distant communal past - "to preserve them by recreating, recording and transmitting them to future generations" - "is a great and durable motive [...] for writing autobiography ${ }^{2 "}$.

Perhaps the most significant comment to make pertaining to these autobiographies is that in preserving the charms and specific qualities of the times that are no more, or in describing and asserting the culture of their indigenous societies by way of autobiography, they do not portray themselves as alienated individuals within their societies as modern Western autobiographers mostly do. They write as inseparable and indistinguishable parts of the group and we perceive that the works are more of group, rather than personal or private, autobiographies. This is due to the fact that in the traditional African society, unlike the modern Western one, the life lived was mainly communal and the individual realized his personality not as an alienated ego but as an integral member of the community.

As would be expected, a number of the details the cultural autobiography utilizes to suggest its communality can be seen, among others, in the traditional attitude towards (a) the circumcision/birth rites (b) the ancestors (c) the relation between the individual and his environment (d) the role of the artist/priest in the community (e) the bearing of a proper name. Each of these aspects of traditional life can stand as a theme in its own right and can be explored as such, but in most cultural autobiographies they are treated as related, inseparable topics which emphasize a common theme, that of communality or group-felt experience, which is what this essay will mainly examine.

All the works cited, to a greater or lesser extent, contain the elements identified above. However, an attempt will be made to pay more detailed attention to Camara Laye's The African Child and Mugo Gatheru's Child of Two Worlds for the simple reason that both works are more representative than the others, since they adequately deal with all or almost all of the items mentioned above.

As has been suggested, one of the details the African cultural or communal autobiography uses to suggest its communality can be seen in the traditional attitude towards rites like circumcision which demonstrate the communal life of the people. In The 
African Child, for example, the circumcision ceremony which Laye describes symbolises a deeply felt sense of communion of friendship of Malinke age-mates, and also signifies an initiation into Malinke manhood. The circumcision ceremony makes the initiate a man, binds him to the land, revives the ancestors through him, and makes the individual completely at one with the group:

I wanted to be born, to be born again. I knew perfectly well that I was going to be hurt, but I wanted to be a man and it seemed to me that nothing could be too painful if, by enduring it, $I$ was to come to a man's estate. My companions felt the same; like myself, they were prepared to pay for it with their blood. Our elders before us had paid for it thus; those who were born after us would pay for it in their turn. Why should we be spared? Life itself would spring from the shedding of our blood. (p. 93)

The circumcision ceremony emphasizes the link between generations, between the initiates and their ancestors (who had performed the ceremony in the past), and between the initiates and their unborn children (who would perform the ceremony in the future). In other words, the circumcision ceremony emphasizes the perpetual continuity of the community and the unity of Malinke culture. And young initiates like Camara Laye are willing to bear pain to be part of this continuing culture.

In Child of Two Worlds, group well-being is also seen to control and define individual existence. In the chapter "Becoming a Kikuyu" Mugo Gatheru, like Camara Laye, spends several pages describing a Kikuyu initiation ceremony which we understand as a realisation of life that fits the individual within the group mold:

I was now allowed to look down at the handiwork of the circumcision and see what had been done to me. Blood was streaming from me like water from a pipe. Thank God I did not faint for I would have been disgraced! The crowd was glad because I had shown courage. They dispersed singing and happy that another Kikuyu child had been brave and had become a man. (p. 61)

The circumcision ceremony that Gatheru describes is similar to the one described by Camara Laye in The African Child. Moreover, and more importantly, what the circumcision ceremony means to a Kikuyu is remarkably similar to what it means to the Malinke. According to Camara Laye, the whole town happily partook in the ceremonial dance that preceded the circumcision and relatives eagerly awaited "the ceremonial shots that would announce to all that one more man, one more Malinke had been born". (p. 102)

Thus for the Kikuyu as well as for the Malinke every individual, especially after his ceremonial circumcision, is a different, new being and something more than an individual: he is a manifestation of a communal soul, the personification of a collective spirit, the representative of Kikuyu and Malinke manhood. As Kenyatta says in Facing Mount Kenya which also describes a similar ritual of circumcision:

The initiation of the circumcision ceremony is the most important custom among the Gikuyu. It is looked upon as a deciding factor in giving a boy [...] the status of manhood in the Gikuyu community. This custom is adhered to by the vast majority of African peoples and is found in almost every part of the continent. (p. 132-133)

What Kenyatta says here about the adherence to this ritual by the majority of African peoples is quite true. Even in a place like South Africa where the political environment is drastically different from elsewhere in the continent we still have evidence that this ritual has always been part of the custom of many African peoples there. In Naboth Mokgatle's The Autobiography of An Unknown South African, for instance, we see that Mokgatle's people, the Sesotho, have always regarded circumcision of the young as one of the key moments of the corporate group which the individual is a part of. Through 
circumcision ceremonies the youth are ritually introduced to the art of communal living and are "taught manhood, tribal laws, customs and traditions" (p. 6). It is also in the circumcision periods that the youth are thaught "how to rear animals, hunting, war as well as herbs and helpful remedies" (p. 6). Thus in the traditional community of the Sesotho the circumcision ceremonies are occasions for the young to learn group-living as well as for acquiring knowledge that would enable them to enter the state of responsibility.

In the above mentioned works, there is no doubt that the basic meaning and significance of the circumcision ceremonies are similar. Despite any differences one may notice in areas of emphasis, all the writers unite in their use of the ritual of circumcision to underscore the communal quality of their narratives.

In Kossoh Town Boy it is not the ritual of circumcision that Cole recalls and gives significance, but that of the birth of a new-born baby. Concluding the fairly long description of the ritual his grandmother performed at the birth of one of his younger brothers, Cole, who rightly assumed that was the exact ritual performed at his own birth, says:

What I have described actually happened. I saw it myself: the same room, the same low bench, the same grandmother, when my brothers Arthur and Wilfred were born and my sisters Phoebe and Irene.

In my mind those events have been telescoped into a symbol, a symbol represented on each occasion, until it did not matter who the central figure was. In this drama the principal actor could be any of us children, including me. I was the first, that is all. (p. 29)

What makes the recollection important is Cole's "universalizing", so to speak, of his own individual experience. His birth is a ritualized experience that is both private, typical and prototypical. The event is one that has not only been experienced by Cole, but also by his brothers and sisters, and even by the generality of his fellow people. As could be argued, birth itself and its attendant ritual may be a common-place, but for Cole it is a common-place that is uniquely representative. Thus, like the circumcision ceremony Laye and Gatheru describe, Cole's description of the ritual performed at his birth (or that of his brothers or sisters) clearly helps to emphasize the point that African life is by and large defined, directed and controlled by ritual repetition, an experience or an event which assumes a communal and archetypal quality.

Another aspect of communal realism is the place belief in the ancestors and spirit occupies in its consciousness. "It", to borrow Obiechina's words, perceives without difficulty the reality of the worlds of spirits, gods and ancestors and the mystical bonds that unite all beings". 3 This sense of communal realism is reflected in a number of the cultural autobiographies treated here. In them we see, for instance, a close correspondence between the world of the living members of the community and that of the ancestors. Any time they have important ceremonies to perform members of the community invoke the names of spirits of the ancestors. The emphasis during such ceremonies is always on the entire observance of the prescribed ritual which must include offering food portions to and pouring libations for the ancestors and saying prayers in their names. For example, in Child of Two Worlds, during the ceremony known as "Njiaro" or the second birth (p. 21), a rite of passage which is meant to guarantee the eleven year-old Mugo Gatheru a full-fledged member status in his clan, prayers are uttered in the names of the ancestors to protect and watch over him and to make him prosperous:

"On, Wamhindu, aaariri (...) (...) (...)"

"Our clan member, you who have died, bless this child that is being born". Another woman called upon another of my ancestors, and in turn, each of the women called upon others. They asked them to protect me, to make me prosperous, and to watch over me. (p. 22) 
The names of the ancestors can also be invoked any time the people are faced with serious problems in lifewhich they want the all-seeing and ever-present ancestors to resolve for them. This deep and abiding faith in the ancestors is one of the chief appeals of Francis Selormey's thinly-disguised autobiography, The Narrow Path:

Torgbui $\mathrm{Zu}$, and all the family gods, behold us here before dawn this day, at the door of your house. Wake up and come to our aid: We are all us children groping in the darkness of this world. We are powerless and we need your help. The wife of your son, Nani is labouring to deliver his child. We beg of you therefore to go to the first home, and to push it into the world. When we return to the house, let the child be quickly and easily born. You are the only one on whom we can rely. Prove now to us that your spirit does indeed live among us, and works for the welfare of those you have left behind. If you do not assist at the birth of your grand-children, who will there be to feed you and remember you? Without your help at such times, your family would die out and be lost from the face of the earth. Torgbui $\mathrm{Zu}$, you know more than we. Send this child quickly and easily ${ }^{4}$.

The ancestors are besought not only to grant health or protection from misfortune, but also to grant children and to assist in the time of their delivery. Prayers to the ancestors occupy so central a place in the narrative scheme of The Narrow Path because they emphasize the redemptive and protective role of the ancestors in the life of the community. The ancestors are a force for social cohesion and should they fail to fulfil the people's ardent yearnings and expectations the historical link of generations will be broken, and the unity of the community will break down: "without your help your family would die out and be lost from the face of the earth". A similar point is eloquently made in Lawrence Vombe's An I11-Fated People where we learn that one reason why the Vashawasha (Shona) community broke up was the failure of the spirits and ancestors to come to the assistance of the people during their decisive battle against colonial conquest and domination:

Perhaps for the first time in their history, the Shona people were shaken out of their blind faith in the Mhondoro spirits and the protection of the ancestors. It was a shattering realization and (...) the disillusioned Shona for a time lost confidence both in themselves as a people and in their traditions ${ }^{5}$.

Indeed, the historical unity of the community can prove transitory and ephemeral, dissolving once the ancestors and spirits fail to help the people to surmount an immediate obstacle.

It must be stressed here that no individual may directly supplicate the ancestors. This is partly because of the importance attached to group participation in any event, and more importantly, because of the importance attached to the supplications as part of the mystical ties that bind the ancestors to their surviving relatives and members of the community. As some of the works cited reveal, the assistance is always sought by the family group if the crises are in the life of the individual, and by the whole people if the crises involve the whole clan or tribe. In the words of Kenyatta:

"Although the crises are in the life of the individual, he may not make supplication on his own behalf; his whole family group must pledge their interest in his life". (p. 235)

\section{Furthermore, if}

"every other occasion again is transcended by crises involving the whole tribe, such as a threatened drought [then], of course, Ngai himself must be appealed to, and the appeal must be made by the active participation of the whole people". 
In an occasion like this, as Kenyatta explains, not only the people, but also the ancestors themselves are invited to join in the appeal and in making the necessary sacrifices to Ngai, "the creator and giver of all things", who is greater than the ancestors. Like Gatheru's, Kenyatta's description makes it clear that the people invite the ancestors by way of pouring them libations and offering them "sacred offerings", acts which symbolise the people's fellowship and ritualised communion with the ancestors.

In Soyinka's Ake: The Years Of Childhood, we are also presented with the reality of the world of the ancestor $S$ and other spiritual beings and the very close correspondence between their world and that of the living. In this narrative, unlike in some of the others, for example Jomo Kenyatta's Facing Mount Kenya, general description of events and mere statements of facts alone are not employed to make "real" this close correspondence between the two worlds. On the contrary, in his narrative Soyinka presents us with specific descriptions of events and rituals which are enactments of not only the "Communion Rite" of spirits and men, but also of gods and men. Right from the first page of the narrative we see, for instance, the egungun, ancestral spirits reanimated in mask performances, whose voices blend with the voice of the Christian deity. In fact, throughout the narrative's early pages the Christian God and Christian services are seen to intermingle freely with African gods, ancestral spirits and traditional rituals. The African Woods and the Christian Orchard, both of which converge at the Canon's house, titillate the young Soyinka's imagination with "marvellous" tales, and they are deliberately recalled because they are surrounded by both the African and Christian spiritual presences:

Only the Canon's residence could have housed the weekly Guest (...) From the upper floor of the Canon's home one almost looked the top of Itoko straight in its pagan eye. It stood at the highest lived-in point of the parsonage, just missing over-looking the gate. Its back turned to the world of spirits and ghommids who inhabited the thick woods and chased home children who had wandered too deeply in them for firewood, mushrooms and snails. (pp. 1-2)

In Ake, Soyinka also underscores his, as well as the African, notion of the close correspondence between the world of the spiritual beings and that of the living with a vivid realization of a series of characters like, for example, his playmate Bukola and uncle Sanya. In the narrative both persons are presented as actual manifestations of the spirits of the other world. Bukola, in particular, is what Soyinka and the Yoruba call abiku -. "a child which is born, dies, is born again and dies in a repetitive circle" (p. 16). She is a "rare, privileged being" (p. 17) who can inhabit the world of the unborn, the world of the dead and the world of the living.

According to Soyinka, Bukola, the abiku:

was not of our world. When we threw our voices against the school walls of Lower Parsonage and listened to them echo from a long distance, it seemed to me that Bukola was one of the denizens of that other world where the voice was caught, seived, re-spun and cast back in diminishing copies. Amulets, bangles, tiny rattles and dark coppertwist rings earthed here through ankles, fingers, wrists and waist. She knew she was abiku. The two tiny cicatrices on her face were also part of the many counter enticements by her companions in the other world. (pp. 15-16)

Clearly, for Soyinka Bukola is a spirit in the midst of the living. She is a reality, a reality which the reader cannot but accept and reckon with, whether it is a transparent, opaque or confused reality. She is not a mere myth of infant mortality, but a manifestation of a communal consciousness, a communal experience, which embraces not only Soyin$\mathrm{ka}$ 's generation but generations past and generations to come as well. 
In Camara Laye's The African Child we also see just how close contact between the world of the living and that of the ancestors and spirits can be. There one of the ancestors is identified as a protective and oracular serpent, "the guiding spirit of our race" who "has always been with us" (p. 17). Like Bukola, - if we must stretch a comparison - the spirit-serpent can appear, disappear and appear again any time he wishes. He is a living and omnipresent reality which links all generations, and maintains mystical bonds and contacts with beings from the visible and invisible universe, the world of the living and the dead, and of nature and the supernatural.

One of the key passages in The African Child, which Camara Laye uses to underline its communality, can be found where he describes the people's collective participation in the rice harvest. In fact, the passage is a crucial one in the narrative scheme of The African Child as it contains several of the details the cultural autobiography uses to suggest its communality. There Camara Laye, for example, vividly and feelingly realizes the close correspondence or relation between man and the environment and between man and the ever-present spiritual beings:

Our husbandmen were singing, and as they sang, they reaped; they were singing in chorus, and reaping in unison; their voices and their gestures were all harmonious, and in harmony; they were one - united by the same task, united by the same song. They were bound to one another, united by the same soul; each and every one was tasting the delight, savouring the common pleasure of accomplishing a common task. (p. 51)

The above is an aspect of Laye's description of the rice harvest in Tindican. In the passage we see the joy of the people as they carry on their yearly ritual of rice harvest. Members of the community who participate in this activity, which assumes the "dimension of a religious ceremony", work in unison, in brotherhood and reach out to one another as well as to the environment. The people are polite to one another, and in spite of the tediousness of the labour involved in the harvesting, they still find time to create an atmosphere of work that is comfortable and a manifestation of their own love and brotherliness.

The environment is similarly unoppressive and favourable, for in the words of Laye himself, the festival of harvesting "depended on the weather, the goodwill of the heavens. It depended perhaps still more on the goodwill of the spirits of the soil, whose influence could not be ignored. If their response was favourable, it only remained to beg of them, on the day before the harvest, to provide sunny skies and protection for the harvesters against the danger of snake bites." (pp. 44-45)

What we see here is a close mystical link between man and his environment. The spirits are ever present on the fields worked by the people, and ever watchful. Although the harvesters cannot escape the scrutiny of these spirits, the environment is nothing but comfortable. And the spirits, "whose influence could not be ignored" are spirits of love and partnership; the vigils they keep are appreciated, for they make the people one with the space within which they work and harvest. This sense of being at peace with and in control of the environment gives even Camara Laye, the estranged youngest member amongst them, a sense of pleasure, confidence and belonging:

Overhead, the swallows would already be skimming lower, though the air would still be clear as ever, but they, too, knew when the end of the day was near. We would go home contented, weary but happy. The good spirits had taken care of us: not one of us had been bitten by snakes that our trampling feet might have disturbed. The flowers, which would begin to unfold with the approach of evening, would be spreading their perfume on the air again, so that we walked as if attired in freshly-plucked garlands. If we had not been singing so loudly, we might have been able to hear the familiar sounds of the close of day: the shouts 
and laughter of women mingling with the lowing of cattle returning to their byres. But we were singing, always singing: Ah! How happy we were in those days. (pp. 53-54)

In order to properly appreciate the above passage, perhaps we should compare it with a passage from Rousseau's The Confessions:

"My imagination, which in my youth always looked forward but now looks back, compensates me with these sweet memories for the hope I have lost forever. I no longer see anything in the future to attract me, only a return into the past can please me, and these vivid and precise returns into the period of which I am speaking often give me moments of happiness in spite of my misfortunes?".

This is an elegiac passage that expresses the feeling of lost happiness, of lost paradise which will never be regained. The time at which these lines were written was a time of affliction and disgrace. To combat it, Rousseau took refuge in the memory of the happy periods of his youth which, as already indicated, will not come back to him again. Everything is highly individualistic, either the past joy recalled or the present feeling of misfortune.

On the other hand, Laye's passage is evocative and expresses a feeling of nostalgia. Like most others it is a passage of "great descriptive authenticity. The feeling of comradeship and shared labour, the simple joy of harvest ${ }^{8 "}$, the sparkling blue weather of the dry season, these are real enough. We see in each of Laye's passages virtues of love and mystery which are demonstrated in the people's warmth of comradeship and shared labour and in the mystical link between man and his environment. These virtues and feelings of communality are virtually absent in Rousseau's The Confessions which, by and large, is romantic and purely self-centred in conception and rendering.

It is necessary to compare The African Child with the other narratives, for example, Child Of Two Worlds, in the light of the point we have been discussing. In Child Of Two Worlds, we see a similar description of group farming, but there the event is not as vivid and feelingly realized as is the case in The African Child:

"Sometimes after the crops had been planted and, while Mother was waiting for them to grow large enough to cut or pull or dig, she would come to the fields where I was herding to bring me food or water. But usually she was too busy for that. Kikuyu women work very hard, cultivating their crops and carrying firewood or water. Sometimes they work together in groups, helping each other. Such groups have a name ngwatio. Often I have heard a group of women - making up songs about things that had happened, or boasting or joking through the words they sang, like this:

LEADER: Tuinire muciare kibura (Let us sing for those who are born Ethaga).

Chorus: Huuh-hoo-aaae-ii-huuh-hioo (yes, it is so)". (p. 20)

Although the "simple joy of harvest" seen here is similar to the one seen in The African Child, the symbolic ritual that attended the activity there is virtually absent here. The feeling of comradeship and shared labour is clearly conveyed, but the mystical link between the individual and his environment is no where demonstrated as is the case in The African Child. In fact, what interests Gatheru in the above description is not the mystical link between the individual and his environment but the group feeling and expression of joy that attends farm work. It is basically this he feels nostalgic about and recalls:

"Sometimes the line grew large with ten or fifteen people, and nobody wanting to admit that he was tired. 
These were happy days, and still today I sometimes think with sadness of this life that I shall never know again, and that, now, my children will never know. (p. 21)

Indeed, that primal world controlled by group well-being is now lost not only to Gatheru, but also to his children or to any-one growing up where Gatheru grew up long ago. The elegiac tone of lost happiness discernable in Rousseau's passage quoted above is also noticed here, but unlike in Rousseau's it is less individualistic since Gatheru uttered it on behalf of himself and others.

An important point to make with respect to the cultural autobiography pertains to how the relationship between the artist and other members of the community suggests its communality. In The African Child, for example, Laye's harvest passages convey this in the relationship between the artist, "the smith-sculptor" who was also a priest" 9 " and the peasant farmer/harvester. The tool the peasant farmer/harvester uses to till and work the soil was produced by the artist, the smith-sculptor, and because there is a close mystical link between the soil and the peasant farmer/harvester who tills it, the tool the latter uses must possess the mystical "power to cut and wound ${ }^{10 "}$. To quote Laye: "The weapons he (the smith-sculptor) produced were able to wound not only because they were sharp and well-tempered, but because the power to cut and wound had been given to them. The hoe of the peasant was not simply the tool with which he turned the earth; it was the tool that ordered the earth and the harvest 11 ". What this implies is that harvesting does not only depend on the "goodwill of spirits of the soil" as already pointed out, but also on the art of the smith-magician whose special skill confers upon him admiration and awe. As Ogungbesan rightly said: "The African Child gave us an insight into the true position of the artist within the traditional African society ${ }^{12}$ ". Laye's father is the revered artist (goldsmith) in the community. His skill commands the people's admiration and fear. However, he does not exploit the situation for, like his people, he realises that his skill must be put to the service of the whole community. He is unlike the European artist as depicted, for example, by James Joyce's Stephen Daedalus:

"I will tell you what I will do and what I will not do. I will not serve that in which I no longer believe, whether it call itself my home, my father-land or my church; and I will try to express myself in some mode of life or art as freely as I can and as wholly as I can, using for my defence the only arms I allow myself to use -- silence, exile and cunning ${ }^{13}$.

The European artist as demonstrated in the above passage sees himself as an outsider who lives alone in his own "individual culture", where the only laws he represents and obeys are those of his imagination. The position of the European artist is very different from that of the African artist who sees himself and his art as part and parcel of his society. Thus, James Joyce or Stephen Daedalus and Laye, as far as art is concerned, belong to two different worlds and cultures. Where Joyce's or Daedalus's art strives towards a solely individual culture, Laye's is oriented to his community's wellbeing.

His art helps to weld his society together:

"In our society it is likely that the smith was, in fact, the first specialised craftsman. The knowledge called for, the number of operations through which the ore must pass before it can betransformed into a weapon or farm implement, all mean specialisation. And once a smith's skill was recognised, rraturally it was to him one went when one wanted something carved - not a simple bowl that any one can make for himself, but statutes of one's ancestors, including the furthest back of all, the totem, or masks for ritual dances; all the cultural objects, in short, that his powers allowed him to consecrate ${ }^{14 "}$. 
To achieve remarkable success in any of these endeavours the artist must be dedicated to his art, as demonstrated, for instance, by Laye's father in his preparations before smithing gold. His strict abstinence from sex and the smearing of his body with lotions which are meant to protect him against evil spirits demonstrate a singular instance of the artist's dedication to his craft and art. Indeed, to be successful in his gold-smithing Laye's father must be ritually pure. His workshop, gold-smithing tools and his own person have to be ritually clean before he ever starts work. If he fails to do this he will not receive the serpent's protection. And it should be emphasized that the serpent is the spirit of Laye's father's race, his family line. As Olney pointed out, "socially and psychologically Camara Laye's father and the race are essentially and indistinguishably one in the extent of their being and (sic) embodiment of the spirit ${ }^{15}$ ". His success is the success of his race and community.

The function of the artist in the traditional African community is similar to that of the traditional healer. Both of them put their knowledge and craft to the service of the community. In Child Of Two Worlds, for instance, Mugo Gatheru informs us that his ancestors, who at one time or another, had borne the name "Mugo" (Gatheru's first name which means "Man of God"), were held in high esteem because they were great seers and heelers:

"When I was born, everyone thought that I would some day be what Americans call a "medicine-man" and what we call a "Mundamungu", for I was in line of those who were believed to have inherited the power, after being properly trained, to control the wind and the unknown forces that make people sicken and die. They had the power, too, to remove the curses known as "thahu", that men brought upon themselves. A "mugo" knew much, and could do much. He had a great responsibility for helping to keep the tribe peaceful, healthy and unafraid. (p. 1)

But unlike Camara Laye who shows us how the artist, his smith-sculptor father, practicalises his skill in art and brings it to the service of the community, Mugo Gatheru is content with merely mentioning the historical fact. He apparently does not consider it significant enough to show us how his seer-healer father performed his divine function. Here, one can see a similarity between Gatheru and Kenyatta who merely informs the reader that "my grand-father was a seer, morathi, or wiseman, whose duty it was to give general advice and for-tell the future as far as he could". (p. 305)

The majority of African peoples trace their ancestry patrilineally and this patrilineal ancestry is underscored by the received or given name which the cultural autobiography also uses to suggest its communality. As Robert Wellesley Cole says in Kossoh Town Boy:

"As to myself I was given at birth the Christian names Robert Benjamin Wellesley Agey (...) Of all these names the only African one is Agey; and for this I have to thank my grandfather (...) Both "Agey" and "Wellesley" are shared by the male members of my family (...) My ancestors seemed to have derived great pleasure from their names and to have passed them on from one generation to another". (pp. 21-23)

And according to Mokgatle:

"When a new male baby was born it was imagined that his dead grandfather had come back to life, and so the child was given dead grand-father's name." (p. 36)

Giving a newborn child a name either for pleasure (this is rare in Africa) or to indicate the reincarnation of an ancestor demonstrates the flexibility and the communality of selfhood in Africa culture; it suggests the extent to which the individual takes part in 
the life of others, and others in his existence. The point, or better, the significance of naming children after the ancestors, is best illustrated in Child Of Two Worlds:

\begin{abstract}
"As the first-born son of one known as Mugo, it was my duty to respect my father and to learn from him, and then, when I was old enough, to take training and to become a "doctor" myself. This, until I was eleven years old, I fully intended to do, and to see that my son after me did the same, so that the great chain of doctors in which I was but a link would never be broken. But the link with my fathers has now been broken and I, Mugo-son-of-Gatheru, will start a new chain, with new links". (p. 2)
\end{abstract}

In the Kikuyu tradition of naming children after specific family members or ancestors, there is an underlying significance that serves to illustrate the general Kikuyu concept of immortality. Every new-born child is not a child until he is named. Its existence, identity and potential actuality are tied to its acquiring the name of, preferably, one of the ancestors who, according to traditional belief, has returned in the new- born child. Thus every individual is an ancestral re-manifestation and embodiment of a communal soul. According to Charity Waciuma, who is Kikuyu like Gatheru,

"In our country names are not chosen haphazardly. Any name includes many people who are now dead, others who are living, and those who are still not born. It binds its owner deep into Kikuyu history, beyond the oldest man with the longest memory. All our relatives to the furtherest extent of the family, their actions, their lives and their children are an intrinsic part of our being alive, of being human, of being African, of being Kikuyu ${ }^{16}$.

In a similar vein Kenyatta tells us in Facing Mount Kenya that "The Gikuyu tribal custom requires that a married couple should have at least four children, two male and two female. The first male is regarded as perpetuating that of the woman's father. The first and second female children fulfill the same ritual duty to the souls of their grandmother on both sides. The children are given names of the persons whose souls they represent. (pp. 163-164)

Thus when Mugo Gatheru, a first-born male child, was given the name of his paternal grandfather, it meant for him, for his family and for the Kikuyu as a whole, that he was in "essence the same as the grandfather, a reincarnation of that person, and that the spirit which both he and his grandfather embody is, through him, guaranteed a continued immortality ${ }^{17 "}$. Mugo Gatheru too was expected to complete this generational link and lineal reincarnation by continuing the same traditional occupation of this grandfather, but this was not to be because, according to him, he and his people, the Kikuyu, have

"been laid on the anvil and are being smelted, hammered, beaten and drawn (...) by the great forces that I have now learned after my college education, to call urbanization, industrialization and acculturation". (p. 2)

Thus a dominant theme in Child Of Two Worlds is Gatheru's anguish and the identity crisis he suffers as a result of his inability to continue living the life of his ancestors and community. The "new chain with new links", that is, a new occupation and new way of life different from the family's, that Gatheru is going to start as a result of European "urbanization, industrialization and acculturation", implies that the inevitable lineal reincarnation which he represents, as suggested by his given name at least, will no longer continue. There is the subtle suggestion that Gatheru is going to live a new, European way of life which encourages and allows a divisible unit of personality, a personal life that allows the notion of a distinct and separated individual who will continue, even after death, "his individuated, private-to-himself, a familial existence!18" 
This conception of existence is foreign to a true Kikuyu. As Kenyatta says:

"According to Gikuyu ways of thinking, nobody is an isolated individual. First and foremost he is several people's relative (...) His life is founded on this fact spiritually and economically, just as much as biologically (...) His personal needs, physical, and psychological, are satisfied while he plays his part as member of a family group, and cannot be fully satisfied in any other way". (pp. 309-310)

What Kenyatta is emphasising here is the communality of existence and the lateral unity that govern the Kikuyu. James Olney defines lateral unity as a "social phenomenon in which the individual is taken as essentially identical with the group and the group as identical with the individual ${ }^{19 "}$. This lateral unity is a fact of Kikuyu autobiography and African autobiography in general and is, among other things, underscored by the given name with all its connotations, For example, Gatheru's discontinuation of the family occupation and his separation from his family and from the ancestral lands make him feel as if he were being torn apart from himself. His anguish is similar to Laye's who also painfully feels his separation from the traditional Malinke community. For instance, by going to school to learn how to read and write, Laye had severed the link with his people and ancestors for he could neither successfully partake in nor continue the ancestral occupation. During the circumcision ceremony which is the core of the traditional custom, we see a demonstration of his profound alienation. The hoe is supposed to be the symbol of his age group, and it is meant to tell everybody present that the boy whose circumcision rite is about to be performed is going to be a good labourer and farmer, but Laye's symbol is an exercise-book and a fountain-pen, which symbolise the alien profession which he has chosen.

Despite their anguish, Camara Laye and Mugo Gatheru still intimately remember and recall in their autobiographies a primal world that is clearly unified by recurrent traditional rituals marking every stage - birth, initiation, marriage, eldership, death - in the life of the individual. Group well-being controlled and defined individual existence.

Our discussion reveals that in The African Child and Child Of Two Worlds, as well as in the other autobiographies cited, the lasting picture we get is not how an individual lives but how a group lives. A record of the ways, motives and beliefs of African traditional culture is what the reader by and large perceives. This picture of native culture that the autobiographers present is similar because all over Africa "the way things really are" is more or less the same. This near homogeneity of experience, motives and belief system, with its ultimate communality, suggests also why several African cultural autobiographies resemble, in a variety of ways, one another so characteristically.

\section{NOTES}

1. LAYE CAMARA (1976), The African Child translated by James Kirkup (1954; rpt. London: Fontana). GATHERU MLGO (1964), Child of Two Worlds (1964; rpt. London: Heinemann). KENYATTA JOMO (1975), Facing Mount Kenya (London: Heinemann).

MOKGATLE NABOTH (1975), The Autobiography of An Unknown South African (Berkeley and Los Angeles: University of California Press).

WELLESLEY COLE, ROBERT (1960), Kassoh Town Boy (Cambridge: Cambridge University Press). SOYINKA WOLE (1981), Ake: The Years of Childhood (London: Rex Collins).

All page references to the texts refer to these editions.

2. OLNEY JAMES (1973), Tell Me Africa (Princeton: Princeton University Press), p. 35.

3. OBIECHINA EMMANUEL (1975), Culture, Tradition and Society in the West African Novel (Cambridge: Cambridge University Press), p. 131, Here Obiechina is speaking in a different, though related, context.

4. SELORMEY FRANCIS (1966), The Narrow Path (London: Heinemann), p. 24.

5. VAMBE LAWRENCE (1972), An Ill-Fated People (London: Heinemann), p. 133.

6. See Wole Soyinka, Collected Plays 1 (Oxford: Oxford University Press), p. 233. 
7. ROUSSEAU J.-J (1981), Les Confessions translated by J.M. Cohen (1953; rpt. Harmondsworth, Middlesex: Penguin), p. 67

8. MOORE GERALD (1980), Twelve African Writers (London: Hutchison), pp. 88-89.

9. LAYE CAMARA (1965), "The Soul of Africa" in African Literature and the Universities: Gerald Moore (ed.) (Ibadan: Ibadan University Press), p. 67.

10. LAYE.

11. LAYE.

12. OGUNGBESAN KOLAWOLE (1973), "Autobiographies in Africa" in Savannah vol. 2, n' 1, June, 4.

13. JOYCE JAMES (1956), A Portrait of The Artist As A Young Man (London: Cape), chap. V.

14. LAYE, "The Soul of Africa", p. 72.

15. OLNEY, Tell Me Africa, p. 128.

16. WACIUMA CHARITY (1969), Daughters of Mumbi (Nairobi: East African Publishing House), p. 8.

17. OLNEY, Tell Me Africa, p. 94.

18. OLNEY.

19. OLNEY, p. 59. 